\title{
EDUCAÇÃO PARA AS RELAÇÕES ÉTNICO-RACIAIS NA FORMAÇÃO DE PROFESSORES DE QUÍMICA: SOBRE A LEI 10.639/2003 NO ENSINO SUPERIOR
}

\author{
Marysson Jonas Rodrigues Camargo a e Anna Maria Canavarro Benite*,a, (®) \\ anstituto de Química, Universidade Federal de Goiás, 74690-900 Goiânia - GO, Brasil
}

Recebido em 06/01/2019; aceito em 06/05/2019; publicado na web em 26/06/2019

\begin{abstract}
EDUCATION FOR ETHNIC-RACIAL RELATIONS IN THE TRAINING OF CHEMISTRY TEACHERS: ABOUT LAW 10.639/2003 IN HIGHER EDUCATION. In this paper, from the experiences of the Collective Ciata, we seek to elucidate theoreticalmethodological aspects that can establish the teaching of Chemistry for education for ethnic-racial relations and the implementation of law 10.639/2003. This research was based on the research-action technique. The recording of the interventions was done followed by transcription and analysis according to the theoretical reference of the analysis of the conversation. Our results show that racism is present in the classroom, therefore, also in Chemistry class. The teacher deals with the real school and must be trained to act in it. It is possible to promote curricular changes in favor of black populations by designing a curriculum that contemplates the ethnic-racial diversity of Brazilian society. Our results showed that it is possible to discuss in a Chemistry class subjects related to the proposals of the mentioned law, as well as, to approach concepts of related chemistry. For this purpose, knowledge was mobilized that were not present in the curriculum of the degree in Chemistry and, therefore, demanded training in service through the group of studies instituted by the Collective Ciata.
\end{abstract}

Keywords: chemistry; africanities; anti-racism; Ciata; LPEQI.

\section{INTRODUÇÃOO}

O racismo anti-negro é um fenomeno estrutural e histórico que sistematicamente discrimina e inferioriza o segmento negro da população brasileira. A base de tal fenomeno é a categoria raça que mesmo não tendo validade enquanto categoria biológica, no mundo social é uma construção que ainda funciona como instrumento de interdição do acesso a direitos socialmente estabelecidos. Em oposição ao racismo, a lei 10.639/03, que alterou a Lei de Diretrizes e Bases da Educação Nacional (LDBEN) tornando obrigatório a instituições públicas e privadas o ensino de cultura africana e afro-brasileira é um marco na luta antirracista e na conquista de direitos da comunidade negra no Brasil. ${ }^{1}$ Entretanto, sobre os obstáculos que a referida lei tem enfrentado na sua implementação: poucas são as iniciativas que tem efetivado as mudanças curriculares nas escolas brasileiras. Dada a perspectiva eurocêntrica de formação da nossa sociedade, principalmente nas universidades, o que significa haver supervalorização de conhecimentos, história e cultura europeias em detrimento das demais sociedades formadoras da nossa civilização, deve-se tomar os devidos cuidados quando se trabalhar os temas demandados pela lei 10.639/03 para que não se ensine sobre África, por exemplo, um continente tão plural, "à luz de conceitos pré-concebidos e legitimados por um modelo conservador de educação (p. 12)". ${ }^{2}$ É necessário, portanto, atuar na formação de docentes que de fato sejam capacitados para implementarem a lei e levantarem debates que abordem a diversidade de conhecimentos que esculpiram a nação brasileira, contemplando, dessa forma, a diversidade étnico-racial das escolas brasileiras. ${ }^{3}$

No Ensino Superior a temática está ainda em sua gênese, muitas vezes ocupando um lugar de figuração nos projetos pedagógicos de cursos e pouco repercutindo em mudanças curriculares. Em trabalho em que foram analisados cursos das Universidades Federal de Santa Catarina e Federal de São Carlos concluiu-se que em muitos casos a simples menção no Plano de Curso, mesmo que fragmentada, do tema faz concebê-lo como contemplado. ${ }^{3}$ Isso significa que os temas

*e-mail: anitabenite@gmail.com são objetivos na formação dos profissionais formados nesses cursos, porém não aparecem nas ementas das disciplinas. Nada obstante, a simples referência a norma dessa temática nos documentos oficiais dos cursos não atende a obrigatoriedade legal, o que se pretende é uma alteração curricular no ensino superior.

Os esforços em levar essa discussão mais especificamente na formação inicial e continuada de professores de Ciências/Química também são tímidos. Os dados de grupos de pesquisas voltadas a implementação da lei 10639/03 cadastrados no Diretório de Grupos de Pesquisas no Brasil (DGP) do Conselho Nacional de Desenvolvimento Científico e Tecnológico (CNPq) constatam que apenas 11 grupos na área de educação desenvolvem linhas de pesquisa abarcando os temas da lei em questão. ${ }^{4}$

Compreendemos o currículo como artefato político - portanto, está relacionado às ideologias, à conformação social e aos mecanismos que o constrói, como o racismo, por exemplo, assim como à cultura e à capacidade de sujeitos ou grupos influenciarem assimetricamente outros segmentos - que reúne conteúdos e práticas docentes a serem desenvolvidos na escola. ${ }^{5}$

O professor e a professora têm a própria cultura e que esta é enriquecida pela sua formação inicial servindo como guia da ação mediada. ${ }^{6}$ Neste sentido as "Diretrizes Curriculares Nacionais para a Educação das Relações Étnico Raciais e para o Ensino de História e Cultura Afro-brasileira e Africana" do MEC fazem algumas orientações. $\mathrm{O}$ documento indica que toda discussão das questões raciais deve ser incluída na matriz curricular da formação de licenciados bem como em cursos de formação continuada.

As mudanças ensejadas por todo esse arcabouço legal edificam uma educação antirracista que, consequentemente, promovem uma ruptura epistemológica e curricular ao incluir a temática afro-brasileira e africana pública e legitimamente. ${ }^{7}$ Todo esse aparato legal e suas resultantes - pesquisas, formação de professores etc. - que atendem a antigas demandas do Movimento Negro, devem ser considerados como mais uma conquista na descolonização do currículo que decorre de planejamentos de emancipação que essencialmente comporta enfrentamentos: 
... o conflito ocupa o centro de toda experiência pedagógica emancipatória. Ele serve antes de tudo para tornar vulnerável e desestabilizar os modelos epistemológicos dominantes e para olhar o passado através do sofrimento humano, que, por via deles e da iniciativa humana a eles referida, foi indesculpavelmente causado. Esse olhar produzirá imagens desestabilizadoras, susceptíveis de desenvolver nos estudantes e nos professores a capacidade de espanto e de indignação e uma postura de inconformismo, as quais são necessárias para olhar com empenho os modelos dominados ou emergentes por meio dos quais é possivel aprender um novo tipo de relacionamento entre saberes e, portanto, entre pessoas e entre grupos sociais. Poderá emergir daí um relacionamento mais igualitário e mais justo, que nos faça apreender o mundo de forma edificante, emancipatória e multicultural (p.107). ${ }^{7}$

Descolonizar currículos refere-se, no presente trabalho, em incluir o legado não visibilizado de culturas que compõem a formação da sociedade e que foram suprimidos pelo eurocentrismo. Kabenguele Munanga, em entrevista, diz que o currículo reflete a história de um país e que em sociedades do Ocidente tem correlação com a dominação, uma vez que a educação é controlada pelo Estado, o qual é orientado por uma elite ideologicamente europeizada. ${ }^{8}$ Munanga ainda adverte que não se trata de trocar um centrismo por outro, o movimento dessas militâncias é o da inclusão dos conhecimentos e culturas dos povos oprimidos. ${ }^{8}$

O legado africano e da diáspora africana deve ser introjetado ao currículo escolar em todas as áreas do conhecimento o que requer, no ensino das ciências da natureza, reconhecer que:

A espécie humana interage e modifica o mundo pelo trabalho. Recorta a realidade mediante um processo reflexivo indispensável a predição de fenômenos naturais ou sociais que têm impacto direto sobre a condição de sua sobrevivência. Desta forma, os conhecimentos científicos/tecnológicos são importantes referenciais para julgamento e seleção de ações na interação com o ecossistema e, portanto, legitimam posições sociais por meio da lógica racional atribuída equivocadamente somente ao europeu (p.137-138). ${ }^{9}$

Há variadas possibilidades para essa ampliação do foco curricular no ensino de Química, por exemplo, propiciando a superação da ideia de que a contribuição africana e afro-brasileira à formação da sociedade brasileira contemporânea se deu apenas nas manifestações folclóricas, culinárias, samba etc. Resgatar a produção de saberes técnicos e tecnológicos de matriz africana e da diáspora em Química é combater a insipiência sobre as origens da vida material e deter a desvalorização da herança cultural africana e afrodescendente tão determinante para a formação da nossa sociedade. ${ }^{9}$

Sem embargo, cabe ressaltar que a cultura científica a que os alunos serão apresentados não deveria hierarquizar cor, etnia, gênero. A ciência e a ideologia se localizam em domínios distintos: a ciência na indagação na qual os critérios de cientificidade são acordados entre os pares historicamente, a ideologia na convicção que se traduz em ação social e política regidas por interesses de determinados grupos. ${ }^{10}$ Sendo assim, a ciência é um constructo da humanidade como um todo e não apenas desenvolvida a partir de uma única matriz. ${ }^{11}$ Porém, as ciências ou mais especificamente a Química que são ensinadas a partir de um viés de currículo eurocêntrico, produzem e reproduzem o racismo estrutural historicamente construído impondo sobre africanos e afrodescendentes um estigma de pessoas que não produziu e/ou produz ciência e tecnologia.

Este trabalho objetiva investigar a seguinte questão: como se pode incluir a temática educação para as relações étnico-raciais na formação de professores de química? Em busca de um possível caminho investigamos especificamente se a discussão sobre a Educação para as Relações Étnico Raciais foi introduzida na formação inicial de professores de química por meio de um grupo de estudos, o Coletivo Ciata, do Laboratório de Pesquisas em Educação Química e Inclusão (LPEQI) do Instituto de Química da Universidade Federal de Goiás.

\section{METODOLOGIA}

Esta investigação foi desenvolvida segundo a técnica de pesquisa-ação, isso é, uma pesquisa focada na melhoria da atuação profissional dos que nela se envolvem. Importa ressaltar que, na pesquisa-ação, os sujeitos da pesquisa são vistos como profissionais que podem resolver problemas a partir da ação refletida. Na Figura 1 resumimos o caminho metodológico dessa pesquisa que se desenvolveu em ciclos espirais caracterizados por cinco etapas. Neste excerto discutimos dados obtidos em um dos ciclos de pesquisa-ação.

Os critérios da escolha da instituição onde realizamos a pesquisa foram: a) ser instituição pública; b) disponibilidade para que trabalhássemos juntos nas disciplinas de Ciências e/ou Química; c) ter o currículo aberto às mudanças: d) ser campo de atuação no estágio; e) parceira do Movimento Negro.

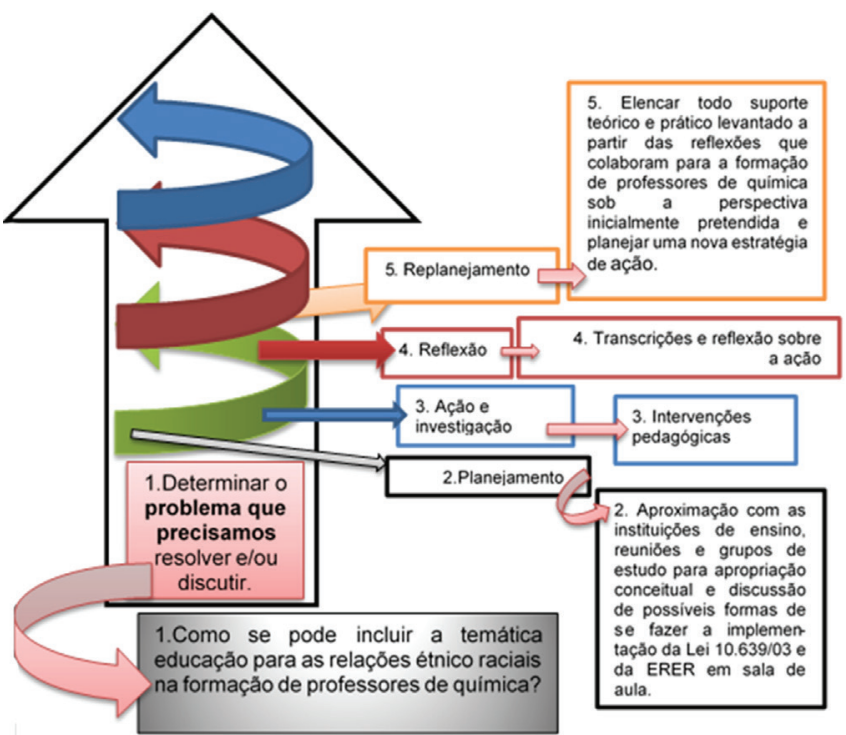

Figura 1. As tessituras do percurso metodológico. Caraterísticas de cada ciclo de pesquisa-ação

O ciclo espiral de pesquisa-ação que optamos por apresentar nesta comunicação foi desenvolvido por professores em formação inicial com alunos do $9^{\circ}$ ano. A parceria com essa instituição surgiu a partir do contato da coordenadora da escola com um dos integrantes do coletivo e o atendimento, por parte da escola, aos requisitos descritos anteriormente. A mesma relatou problemas com situações de racismo na escola e que a professora de Ciências estaria aberta à nossa colaboração nas intervenções pedagógicas do $9^{\circ}$ ano, no qual os alunos são iniciados no conhecimento químico. As intervenções pedagógicas que ministramos foram sempre no turno vespertino a cada quinze dias.

A partir da escolha da escola parceira, o desafio que primeiro nos instigou a pesquisar foi pensar em como ensinar história e cultura africana e afro-brasileira no ensino de Química. É um desafio porque a nossa grade curricular por intermédio das disciplinas específicas do curso de licenciatura (vide Quadros 1 e 2 abaixo) não abria espaço para que pudéssemos ter acesso a referenciais que nos dessem suporte para essa discussão. Logo, tivemos que construir o nosso 
Quadro 1. Disciplinas componentes do curso de licenciatura em Química da Universidade Federal de Goiás - Campus Samambaia

\begin{tabular}{|c|c|c|c|}
\hline Número & Disciplina & $\begin{array}{c}\text { Carga } \\
\text { horária } \\
\text { semestral }\end{array}$ & Natureza \\
\hline 1 & Bioquímica & 64 & OBR \\
\hline 2 & Cálculo 1-B & 64 & OBR \\
\hline 3 & Cálculo 2-B & 64 & OBR \\
\hline 4 & Didática & 64 & OBR \\
\hline 5 & Disciplina de Núcleo Livre & 64 & LIV \\
\hline 6 & Disciplina de Núcleo Livre & 64 & LIV \\
\hline 7 & Disciplina Optativa & 64 & OPT \\
\hline 8 & Epistemologia da Ciência & 32 & OBR \\
\hline 9 & Estágio de Licenciatura 1 & 100 & OBR \\
\hline 10 & Estágio de Licenciatura 2 & 100 & OBR \\
\hline 11 & Estágio de Licenciatura 3 & 100 & OBR \\
\hline 12 & Estágio de Licenciatura 4 & 100 & OBR \\
\hline 13 & Estrutura e Propriedade da Matéria & 64 & OBR \\
\hline 14 & Física 1 & 64 & OBR \\
\hline 15 & Física 3 & 64 & OBR \\
\hline 16 & Físico Química Experimental 1 & 64 & OBR \\
\hline 17 & Físico Química 1 & 64 & OBR \\
\hline 18 & Físico Química 2 & 64 & OBR \\
\hline 19 & Físico Química 3 & 64 & OBR \\
\hline 20 & FQ Experimental 2 & 64 & OBR \\
\hline 21 & Fundamentos de Mineralogia & 64 & OBR \\
\hline 22 & $\begin{array}{l}\text { Fundamentos Filosóficos e Sócio- } \\
\text { Históricos Educação }\end{array}$ & 64 & OBR \\
\hline 23 & Inorgânica Experimental & 64 & OBR \\
\hline 24 & $\begin{array}{l}\text { Instrumentação para o Ensino de } \\
\text { Química }\end{array}$ & 64 & OBR \\
\hline 25 & $\begin{array}{l}\text { Introdução à Língua Brasileira de } \\
\text { Sinais - LIBRAS }\end{array}$ & 64 & OBR \\
\hline 26 & Políticas Educacionais & 64 & OBR \\
\hline 27 & Psicologia da Educação 1 & 64 & OBR \\
\hline 28 & Psicologia da Educação 2 & 64 & OBR \\
\hline 29 & Química Ambiental & 96 & OBR \\
\hline 30 & $\begin{array}{l}\text { Química Analítica Experimental } \\
\text { Qualitativa }\end{array}$ & 64 & OBR \\
\hline 31 & $\begin{array}{l}\text { Química Analítica Experimental } \\
\text { Quantitativa }\end{array}$ & 64 & OBR \\
\hline 32 & Química Analítica Qualitativa & 32 & OBR \\
\hline 33 & Química Analítica Quantitativa & 32 & OBR \\
\hline 34 & Química dos Elementos & 64 & OBR \\
\hline 35 & Química e Sociedade & 32 & OBR \\
\hline 36 & Química Inorgânica & 64 & OBR \\
\hline 37 & Química Orgânica 1 & 64 & OBR \\
\hline 38 & Química Orgânica 2 & 64 & OBR \\
\hline 39 & Química Orgânica Experimental 1 & 64 & OBR \\
\hline \multirow[t]{2}{*}{40} & Transformações Químicas & 128 & OBR \\
\hline & Total & 2672 & \\
\hline
\end{tabular}

Legenda: OBR - OBRIGATÓRIA, LIV - LIVRE, OPT - OPTATIVA Fonte: ref. 12

estado da arte e conhecer referenciais que não estão nas estantes de livros da área de Ensino de Química e partir para a ação focados em planejar e intervir.

Conforme mostra o Quadro 2, as disciplinas como "Estágios de Licenciatura 1, 2, 3 e 4" e "Instrumentação para Ensino de Química" não possuíam incluídos em seus ementários referenciais e discussões que contemplassem a proposta da lei 10.639/2003. Assim, mediante esse cenário, o Coletivo Ciata, buscando em autores como Henrique Cunha Júnior, Kabengele Munanga, Cheik Anta Diop, Nilma Lino Gomes e outros (as), desenvolveu estratégias de intervenções pedagógicas para implementação da lei 10639/03. O Coletivo Ciata, como um grupo de estudos, poderia ser, portanto, o meio pelo qual inseriríamos a educação para as relações étnico-raciais e a implementação da lei 10639/2003 como componente curricular na formação de professores de Química.

Quadro 2. Ementário de disciplinas com possibilidade de discussões afins a proposta da Lei 10.639/2003 e ERER

\begin{tabular}{|c|c|}
\hline Disciplina & Ementa \\
\hline $\begin{array}{l}\text { Estágio de } \\
\text { Licenciatura } 1\end{array}$ & $\begin{array}{l}\text { Caracterização do perfil do professor de Ensino Básico } \\
\text { do Estado de Goiás. A formação inicial e continuada } \\
\text { de professores. A realidade pedagógica do Estado de } \\
\text { Goiás. Introdução à pesquisa no ensino de Química. }\end{array}$ \\
\hline $\begin{array}{l}\text { Estágio de } \\
\text { Licenciatura } 2\end{array}$ & $\begin{array}{l}\text { Análise, discussão e elaboração de materiais didáticos. } \\
\text { Experiências de ensino na escola: análise e discussão. } \\
\text { Desenvolvimento de projetos de pesquisa em Educa- } \\
\text { ção em Química e Ciências iniciados no Estágio de } \\
\text { Licenciatura } 1 \text {. }\end{array}$ \\
\hline $\begin{array}{l}\text { Estágio de } \\
\text { Licenciatura } 3\end{array}$ & $\begin{array}{l}\text { Atividades de semi regência e regência em escolas } \\
\text { da educação básica. Desenvolvimento de pesquisa na } \\
\text { área de Ensino de Química conforme projeto iniciado } \\
\text { no Estágio de Licenciatura 1. Diretrizes Curriculares } \\
\text { Nacionais para Formação de Professores da educação } \\
\text { Básica com foco na formação de licenciados em Quí- } \\
\text { mica. Abordagem de temáticas relacionadas às atuais } \\
\text { tendências do Ensino de Química na formação inicial. }\end{array}$ \\
\hline $\begin{array}{l}\text { Estágio de } \\
\text { Licenciatura } 4\end{array}$ & $\begin{array}{l}\text { Atividades de semi regência e regência em escolas da } \\
\text { educação básica. Finalização da pesquisa na área de } \\
\text { Ensino de Química: escrita do texto final e apresen- } \\
\text { tação no Seminário de Estágio da Licenciatura em } \\
\text { Química. Abordagem de temáticas relacionadas às } \\
\text { atuais tendências do Ensino de Química na formação } \\
\text { inicial. Discussão de conceitos estruturadores do co- } \\
\text { nhecimento químico em sua relação com a docência } \\
\text { na educação básica. }\end{array}$ \\
\hline $\begin{array}{l}\text { Instrumentação } \\
\text { para Ensino de } \\
\text { Química }\end{array}$ & $\begin{array}{l}\text { Discussão sobre a natureza do conhecimento químico } \\
\text { e suas implicações no Ensino Básico (visão tradicio- } \\
\text { nal vs. tendências recentes). Contribuições históricas } \\
\text { da experimentação na construção do conhecimento } \\
\text { químico. Importância da experimentação no Ensino de } \\
\text { Química. Abordagens alternativas da experimentação } \\
\text { no ensino de química. }\end{array}$ \\
\hline
\end{tabular}

Fonte: Adaptado de Projeto Político Pedagógico do Curso de Licenciatura em Química (p. 25-27, 34). ${ }^{12}$

Os sujeitos deste ciclo foram PF1, PF2, PS, A1, A2, A3, A4, A5, A6, A7, A8, A9, A10, A11, A12, A13, A14, A15 e A16. PF1 e PF2 professor em formação 1 e professora em formação 2, respectivamente - eram no ano em questão (2013) alunos do curso de licenciatura em Química da Universidade Federal de Goiás, ambos não haviam ainda passado pelo Estágio Supervisionado do curso de licenciatura e, portanto, não tinham experiência em sala de aula, porém ambos eram membros do coletivo Ciata e alunos de iniciação científica.

A PS - professora supervisora - já era servidora na escola e professora oficial da turma na disciplina de Ciências do $9^{\circ}$ ano (C9). De A1 até A16 representam os alunos e alunas da turma em que atuaram PF1 e PF2. Todas e todos as/os alunos/as eram matriculados regularmente e com idades compatíveis a séria em curso. As intervenções nesta disciplina foram gravadas por registro fílmico para posterior transcrição e análise. 
Nossos resultados foram analisados por intermédio da técnica de análise da conversação. Assim, temos por base que, enquanto ser que fala, o ser humano faz da língua oral uma atividade comunicativa entre dois ou mais interlocutores que desenvolvem turnos de fala sobre variados assuntos. ${ }^{13}$ A conversação é um processo de socialização, no qual seres humanos podem mediar entre si conhecimentos, logo pode ser classificado como simétrico quando os falantes ocupam posições iguais ou assimétrico quando pelo menos um dos interlocutores tem maior influência sobre os demais partícipes do diálogo, como é o caso do uso da língua falada, por exemplo, em sala de aula na qual o professor ocupa posição de autoridade no assunto. ${ }^{14}$

\section{RESULTADOS E DISCUSSÕES}

A seguir apresentamos o plano de aula (Quadro 3) da intervenção pedagógica selecionada para caracterizar o primeiro ciclo da pesquisa: uma de nossas primeiras intervenções na educação básica. A IP intitulada "Relações étnico-raciais e transformações químicas: as leis ponderais" - aconteceu em 16 de setembro de 2013 em uma escola da rede pública estadual de tempo integral do estado de Goiás na região sudoeste da Grande Goiânia. A intervenção teve duração de 50 minutos, da qual foram produzidos 608 turnos de discursos.

Quadro 3. O planejamento da intervenção pedagógica

\begin{tabular}{|l|l|}
\hline \multicolumn{2}{|l|}{$\begin{array}{l}\text { Intervenção Pedagógica: 16/09/2013 "Relações étnico-raciais e transfor- } \\
\text { mações químicas: as leis ponderais" }\end{array}$} \\
\hline Tempo utilizado & 50 minutos \\
\hline Desenvolvimento & $\begin{array}{l}\text { No primeiro momento apresentamos aos alunos o } \\
\text { contexto das relações étnico-raciais no Brasil e sobre } \\
\text { como pessoas negras são vistas pela sociedade. Em } \\
\text { um segundo momento discorremos sobre o legado } \\
\text { africano para humanidade. A forjaria do ferro no } \\
\text { continente africano. Em um terceiro momento dis- } \\
\text { cutimos sobre o conceito de transformação da matéria } \\
\text { e características de fenômenos químicos envolvidos } \\
\text { na forja do ferro. Em um quarto momento execu- } \\
\text { tamos um experimento utilizando balança de pratos; } \\
\text { Em um quinto momento a partir da experimentação } \\
\text { conceituamos a Lei de Conservação da Matéria. }\end{array}$ \\
\hline Experimento & $\begin{array}{l}\text { Materiais: 1 balança de comparação de pesos. 2 } \\
\text { porções iguais de esponja de aço e fósforos. Pro- } \\
\text { cedimento: Colocar as porções de esponja nos pratos } \\
\text { da balança e equilibrá-los. Queimar uma da esponja } \\
\text { utilizando fósforos, observar e anotar o que acontece. }\end{array}$ \\
\hline $\begin{array}{l}\text { Estratégia de } \\
\text { avaliação }\end{array}$ & $\begin{array}{l}\text { Compreender que o legado africano não se resume } \\
\text { apenas em manifestações folclóricas, mas também na } \\
\text { produção de conhecimento a respeito da natureza; e } \\
\text { a partir deste contexto entender a lei de conservação } \\
\text { das massas em reações químicas. }\end{array}$ \\
\hline Análise da transcrição do registro fílmico.
\end{tabular}

A fase inicial de planejamento desse ciclo começou pela reflexão de que a ciência é um empreendimento social e historicamente construído, o que implica dizer que a ciência é resultado da colaboração entre vários povos do planeta ao longo da história da humanidade. Reiteramos que "a ciência moderna, portanto, não surgiu de um dia para o outro, nem a partir de uma única proposta (pag. 79) ". ${ }^{11}$ Essa visão não hegemônica está materializada no plano acima (Quadro 3) quando, a partir da divisão da intervenção pedagógica em cinco momentos, planejamos discutir sobre o legado africano e a lei ponderal de conservação de massas a qual ficou notoriamente conhecida como uma contribuição do cientista químico francês Antoine Laurent Lavoisier (1743 - 1794).

Não concordamos que a Química foi fundada por Lavoisier com o livro Traitté elementaire de chemie (1789) - quando no mesmo ele enuncia a Lei de Conservação das Massas sendo considerado por muitos o "pai da Química Moderna" - ou mesmo que esse fundador tenha sido o inglês Robert Boyle (1627 - 1621) com seu sistemático estudo dos gases ideais. ${ }^{15}$ Técnicas e ferramentas, portanto, conhecimentos criados e utilizados por nossos ancestrais também provocaram grandes transformações:

O trabalho foi o passo decisivo para a transformação de nossos ancestrais, e a descoberta de ferramentas foi um momento-chave nessa transformação. Logo se descobriu como operar melhorias nas ferramentas primitivas. Novos materiais foram descobertos: chifres, dentes, conchas, fibras vegetais, couro e cascas converteram-se em martelos, peneiras, arcos, agulhas, raspadores, trituradores. Começava a construção do arsenal tecnológico, e com esse início surgiu o fabrico de cordas e redes de fibras e um interminável aperfeiçoamento de novas tecnologias até os dias atuais (p. 20). ${ }^{15}$

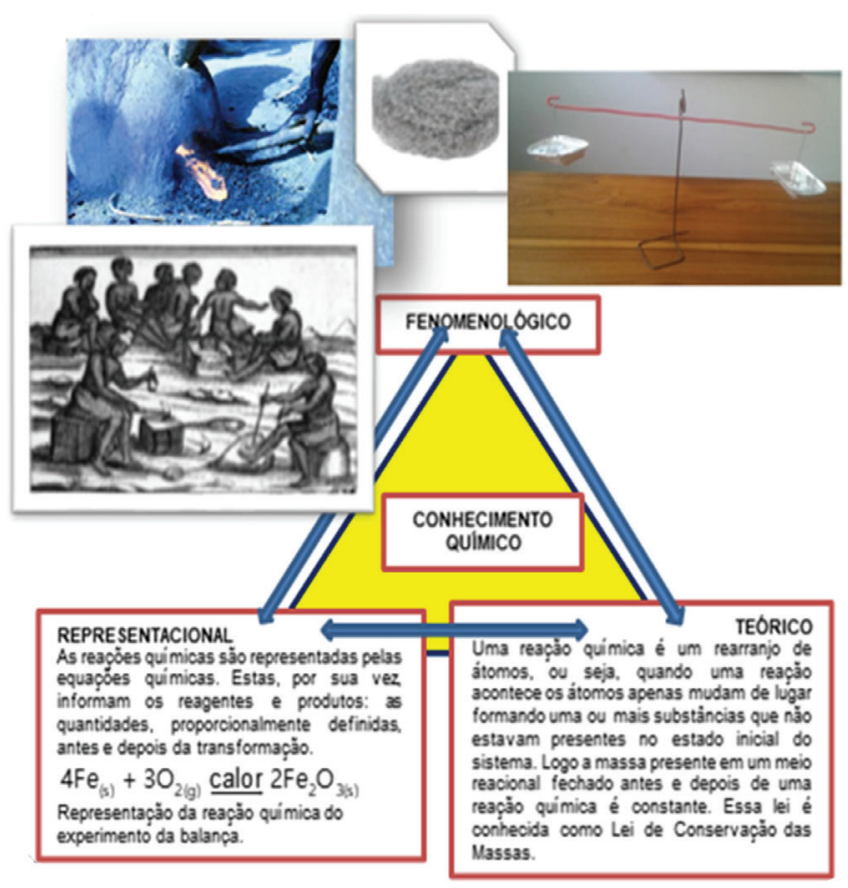

Figura 2. A IP planejada conforme os três níveis do conhecimento químico

O Quadro 3 mostra que o primeiro e segundo momentos foram planejados para viabilizar o ensino de uma ciência que incorpore em seu repertório de conteúdos não somente as culturas produzidas em um espaço-tempo singular, mas que abarque experiências com a natureza de todos os povos e, principalmente, em se tratando do Brasil, as matrizes étnicas formadoras da sociedade brasileira. Portanto, conforme representamos na Figura 2, a ação mediada foi planejada de modo que a prática docente abordasse os três aspectos do conhecimento químico: o fenomenológico, o teórico e o representacional.

A seguir passamos a analisar e discutir o Extrato 1 dessa intervenção pedagógica intitulado "Discutindo Racismo e o Legado Africano na Aula de Química" de C9:

Extrato 1/C9: Discutindo Racismo e o Legado Africano na Aula de Química

165. PF1: Gente, fenótipo é aquilo que a gente consegue 
visualizar da sua genética, entendeu?! Você visualmente é negra.... Fenotípica se refere a ter certa altura, ter o olho de uma determinada cor, isso é o nosso fenótipo, entenderam? 166. Alunos: Sim.

167. PF1: É o que está na nossa aparência, como a professora falou ali, o que é visual - percebido socialmente - em nós, se eu inferiorizo ou superiorizo alguém por isso eu estou sendo racista.

168. A2: Racista.

169. PF1: Injusto, o racismo é injusto né, e o racismo também é crime, existe a lei 7.716 de 5 de janeiro de 1989, que completou 25 anos esse ano, que criminaliza atos de racismo. O que seria isso? Você não deixar alguém entrar nessa sala aqui porque ela é negra, você falar mal de alguém, diminuir alguém porque ela é negra, isso é o racismo.

170. A16: Discriminar ele por causa da cor dele, falar: sai daqui, porque você é preto!

183. PF1: Os negros que foram tirados da sua terra, da sua nação, e foram levados, foram traficados, na verdade né, para outros países. A diáspora significa dispersão de um povo, eles pegaram os africanos, os brancos, e europeu, os traficantes de negros, então eles pegavam eles daqui de um certo país da África. (PF1 apresenta neste momento o Mapa da Diáspora). 185. PF1: Então, daqui eles eram levados para as Américas, para Europa, entenderam? E esse povo, será que eles não tinham nada de conhecimento ou tinham?

186. A6: Tinham.

187. PF1: Eles tinham uma história na nação deles, eles tinham conhecimentos, todas suas produções culturais, $e$ também tinham sua forma de produzir.

188. A6: comidas, roupas...

189. PF1: Para viverem, ali onde eles viviam. Então aos africanos, é atribuída aos africanos, sabe uma transformação superimportante. Sabem qual é? Sabe qual foi aliás? A descoberta do fogo. Vocês pensam que, gente isso revolucionou demais a história da humanidade não foi?!

190. A7: Igual naquele filme que chama "A guerra do fogo"! 191. PF 1: O quê que a gente pode fazer com ofogo? A gente pode cozinhar.

192. A7: Se aquecer.

193. A1: Se queimar.

194. PF1: Aquecer, se queimar também, tenho certeza que um dos primeiros a descobrir o fogo colocou o dedo lá para ver né, porque era uma coisa diferente, então é atribuída aos africanos a descoberta do fogo, que era usado para transformar o quê? Para transformar a matéria né? O quê que é matéria?

195. A7: O alimento! Alimento é matéria!

197. PF1: Matéria é tudo o que nos cerca, o que modificamos produzindo a cultura ...

198. Alunos: tudo!

199. PF1: Então, com o fogo eles puderam transformar a matéria. Como eu transformo a matéria? Cozinhando, né, reagindo uma coisa com uma outra coisa para obter o produto que eu quero né, os africanos também desenvolveram a mais antiga técnica de forja do ferro.

201. PF1: Vocês acham que se encontra ferro desse jeito da natureza (apontando para um objeto de ferro)?

202. Alunos: Não!

203. PF1: Na natureza temos os minérios, estes são constituídos de uma substância chamada óxido de ferro que deve ser transformada.

204. A7: Podemos levar ao fogo.
205. PF1: Levava onde? Leva ao fogo né, tinha um forno que eles transformavam o minério em ferro metálico? E isso é o quê? Uma transformação, não é?

207. ... PF1: Bom, e a técnica de forja do ferro mais antiga que, que se tem conhecimento, que é africana, ela foi utilizada no Brasil até na metade do século XIX, então, é uma técnica africana que é um elemento da...?!

208. Alunos: Diáspora.

209. PF1: Da diáspora africana, nossos ancestrais vieram para cá só para trabalhar e obedecer a ordens? Não né.... . Então agora nós vamos passar para uma próxima parte da aula que é com a PF2.

211. PF1: Ela vai fazer um experimento com vocês sobre transformações da matéria.

O Extrato 1 começa com PF1 fazendo referência ao racismo, tentando dar exemplos de como ele se materializa na sociedade nos turnos 165 e 167. No turno 169, PF1 argumenta por meio da intertextualidade e o discurso de autoridade quando se refere ao texto da lei 7.716 de 1989 objetivando, dessa forma, o entendimento dos alunos de que racismo é crime e como tal deve ser denunciado e não praticado.

PF1 é intertextual, pois cita o texto da lei 7.716/1989, reafirmando-o. Ao mesmo tempo, ao enunciar tal referência, ou seja, um texto com força de lei, PF1 faz o uso do discurso de autoridade, talvez na tentativa de inibir seus alunos à prática do racismo. No turno 170, A16 na produção da contrapalavra parece compreender ao dar o exemplo de uma situação que ele considera racista: "Discriminar ele por causa da cor dele, falar: sai daqui, porque você é preto!".

A partir dos turnos 183 e 185, PF1 começa a discutir sobre o conceito de diáspora africana com o auxílio do Mapa da Diáspora presente no kit "A cor da cultura III". Nos turnos 187 e 189 o professor ainda discute que os povos africanos ao serem transportados de sua terra originária para outras nações, como o Brasil, impactaram estes novos espaços com a sua cultura, PF1 reafirma esta posição no turno 209 quando questiona se os africanos trouxeram para a América Portuguesa apenas sua força de trabalho e de pronto responde, negativamente, à própria questão.

Africanos e seus descendentes foram resistentes em compartilhar com seus algozes europeus conhecimentos e tecnologias que poderiam enriquecê-los ainda mais, sendo, portanto, necessários mais estudos sistematizadores da contribuição africana no Brasil. Contudo, podemos citar tecnologias africanas legadas por intermédio da diáspora africana que trouxe para o Brasil mão-de-obra qualificada para determinadas atividades econômicas. ${ }^{16}$

A bateia, instrumento utilizado em técnica de mineração africana, amplamente utilizado em um dos ciclos de desenvolvimento no Brasil Colônia - o Ciclo do Ouro - figura um dos mais representativos objetos não religiosos originários no continente africano e introduzido no Brasil e, podemos tomá-lo como exemplo de elemento da cultura africana que impactou a vida social na sociedade brasileira a partir do século XVII. ${ }^{17}$

Escravizados oriundos da Costa da Mina (conhecidos como os "Mina") - região que atualmente corresponde aos territórios dos países africanos Gana, Togo, Benin e Nigéria - eram associados a uma capacidade inigualável em descobrir o ouro.

A entrada maciça dos Mina na região fomentou, então, essa crença. Mas guardou, também, outros significados. Esses homens e mulheres africanos, embarcados na Costa da Mina com destino ao Brasil, eram tradicionais conhecedores de técnicas de mineração do ouro e do ferro, além de dominarem antigas técnicas de fundição desses metais. Eles conheciam muito mais sobre a matéria que os portugueses, antigos 
parceiros comerciais dos reinos negros da África, vorazes consumidores do ouro desse continente e senhores de enorme extensão territorial no Novo Mundo. Ao que parece, o poder quase mágico dos Mina para acharem ouro e a sorte na mineração associada a uma concubina Mina eram, na verdade, aspectos alegóricos de um conhecimento técnico apurado, construído durante centenas de anos, desde muito antes de qualquer contato com os reinos europeus da era moderna. A opção dos traficantes luso-brasileiros por escravos da Mina, principalmente durante a segunda metade do século XVII e a primeira do século XVIII, fundou-se nesse know-how mineratório e metalúrgico dos negros. Tratou-se, pois, de equipar a região mineradora da Colônia com mão-de-obra especializada. Ao contrário, então, do que se tem pensado em geral, o tráfico atlântico de escravos obedeceu, ainda que parcialmente, a parâmetros originados de demandas específicas, como, por exemplo, as surgidas entre os mineradores coloniais (p. 187,188). ${ }^{17}$

A partir do turno 183, PF1 começa a exemplificar contribuições africanas que impactaram culturalmente as sociedades: o fogo e o beneficiamento de minério de ferro. Defendemos que a química enquanto ciência que descreve, analisa e discorre sobre a matéria e suas transformações produzindo conhecimentos, técnicas e tecnologias que reverberam na vida social deve combater, quando ensinada na escola, a insipiência da sociedade quanto à sua própria história e a participação dos vários povos em sua construção, inclusive o povo africano e a diáspora. ${ }^{18}$

Sobre a descoberta do fogo no continente africano citada por PF1 no turno 189, a mesma ocorreu no Quênia há mais de um milhão e quatrocentos mil anos atrás onde o nosso ancestral Homo erectus aprendeu a controlar o fogo - reação de combustão - é de lá a evidência mais antiga desse fato, pois, segundo os arqueólogos, esse ancestral sepultava seus mortos utilizando-se de argila vermelha que para ficar enrijecida tal como foi encontrada, neste sítio arqueológico, era necessário um aquecimento de no mínimo $400{ }^{\circ} \mathrm{C} .{ }^{19}$

Fica a seguinte indagação: por que temas como esses não são apresentados nos currículos escolares? Todo legado que não atende ao etnocentrismo europeu tende a ser colocado à margem da história $\mathrm{e}$ invisibilizado. Ou seja, o currículo reduz a totalidade de experiências e conhecimentos de todos a quem deveria representar à particularidade de um determinado grupo com vistas a supremacia do mesmo. ${ }^{20}$

Nos turnos 199, 201, 203 e 205, PF1 discorre sobre a técnica de forjaria do ferro africana como sendo a mais antiga técnica e que essa foi importada para o Brasil através da diáspora africana. No turno 207 PF1 afirma que essa técnica foi utilizada no Brasil até meados do século XX. No que diz respeito à anterioridade dos africanos na invenção da forja do ferro, citamos:

O uso do ferro em fundição e forjaria, aparece na África Ocidental em 1200 a. C., tornando-se um dos primeiros lugares para o nascimento da Idade do Ferro. Antes do século 19, métodos africanos de extração de ferro foram empregados no Brasil, até que métodos europeus mais avançados fossem instituídos (p. 36). ${ }^{19}$

O ferro é o vigésimo sexto elemento da tabela periódica, ou seja, tem número atômico igual a 26 prótons. A massa molar do elemento ferro é de aproximadamente $55,845 \mathrm{~g} / \mathrm{mol}$ considerando que o mesmo possui quatro isótopos em diferentes abundâncias. Dentre as suas propriedades físicas citamos as temperaturas de fusão e ebulição, que são $1535^{\circ} \mathrm{C}$ e $2862{ }^{\circ} \mathrm{C}$, respectivamente. ${ }^{21}$

$\mathrm{O}$ ferro ocorre na natureza constituindo minérios como, por exemplo, a hematita $\left(\mathrm{Fe}_{2} \mathrm{O}_{3}\right)$, a magnetita $\left(\mathrm{Fe}_{3} \mathrm{O}_{4}\right)$, a pirita $\left(\mathrm{FeS}_{2}\right)$, entre outros. A obtenção do ferro no estado de oxidação zero pode ocorrer, endotermicamente, por redução direta ou indireta. No estado metálico, o ferro está presente puro ou em proporções diversas em uma variedade infinda de materiais. O ferro é o principal constituinte do aço, que, por sua vez, é uma liga metálica ou uma solução de ferro com até $2,00 \%$ de carbono além de percentagens bem menores de elementos remanescentes do processo de fabricação do aço que é um material utilizado da construção civil ao uso doméstico. ${ }^{21,22}$

A transformação do minério em utensílios indica o uso de operações unitárias nas quais o material passa por transformações físicas e químicas até chegar ao ferro no estado de oxidação zero. O objetivo dos estudos arqueológicos é desvelar e sistematizar esses processos e como foram utilizados nos passados mais remotos. Assim, no contexto da África Ocidental, há mais de cinco milênios o ser humano passou a deliberadamente fabricar utensílios de ferro a partir do beneficiamento de minérios correlatos:

A primeira fase na arte da fabricação de metais envolve a separação do metal no minério dos outros elementos com os quais é combinado. Entre os mais importantes destacamos o oxigênio. O oxigênio deve ser eliminado com a ajuda de outro composto químico (como o carbono no carvão vegetal). Portanto o metal é obtido por meio de uma redução sucessiva desses óxidos. Os outros elementos contidos no minério (ganga) são expulsos em graus variados na forma de escória (p. 65, tradução nossa). ${ }^{23}$

Efetivamente, o processo começava ainda na prospecção e garimpo de matéria-prima, ou seja, nos critérios de escolha do minério a ser beneficiado e nas estratégias de obtenção do mesmo. A maior parte do minério de ferro era obtida em minas superficiais, mas existem alguns casos de minas com mais de dez metros de profundidade. ${ }^{23}$ Em seguida, o minério era preparado para ser colocado no forno o que poderia envolver procedimentos, tais como, lavagem, trituração, esmerilhação, separação, calcinação, etc. Posteriormente, o minério era disposto no forno que fora construído, especificamente, para esse fim. ${ }^{23}$

O forno era obtido a partir do uso de material cerâmico refratário no qual eram misturadas porções variáveis de carvão vegetal e minério de ferro que, na presença de oxigênio atmosférico, eram queimados chegando a temperaturas altas, mas menores que a temperatura de fusão do ferro. O produto final desse processo era uma esponja de ferro metálico e aço com outras impurezas. Nas imagens da Figura 3 podemos observar modelos de forno, escórias e as esponjas de ferro com as impurezas produzidas. ${ }^{23}$

Nos modelos de forno representados acima, a redução dos óxidos acontece via reação de redução direta, que pode ser representada pela equação 1, na qual o óxido de ferro, representado pela hematita, é reduzido a Fe metálico. Assim o carbono, presente no carvão, queima produzindo dióxido de carbono e calor (Equação 2), porém, é necessário o calor produzido na combustão e o carbono em excesso para ocorrer a redução direta da hematita:

$$
\begin{gathered}
2 \mathrm{Fe}_{2} \mathrm{O}_{3(\mathrm{~s})}+3 \mathrm{C}_{(\mathrm{s})} \rightarrow 4 \mathrm{Fe}_{(\mathrm{s})}+3 \mathrm{CO}_{2(\mathrm{~g})} \\
\mathrm{C}_{(\mathrm{s})}+\mathrm{O}_{2(\mathrm{~g})} \rightarrow \mathrm{CO}_{2(\mathrm{~g})}+\text { calor }
\end{gathered}
$$

A escória produzida nessas operações era composta, principalmente, por óxidos de ferro e silicatos. Porém, o ferro reduzido não será o único elemento nos produtos, pois estarão presentes impurezas e nem todo o carbono será oxidado a gás carbônico, preenchendo interstícios da rede cristalina do ferro reduzido. A solução ferro e carbono em diferentes proporções é o que denominamos de aço. $\mathrm{O}$ 

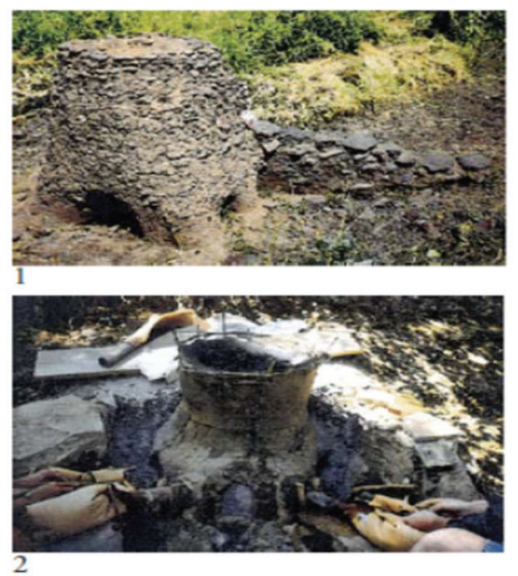
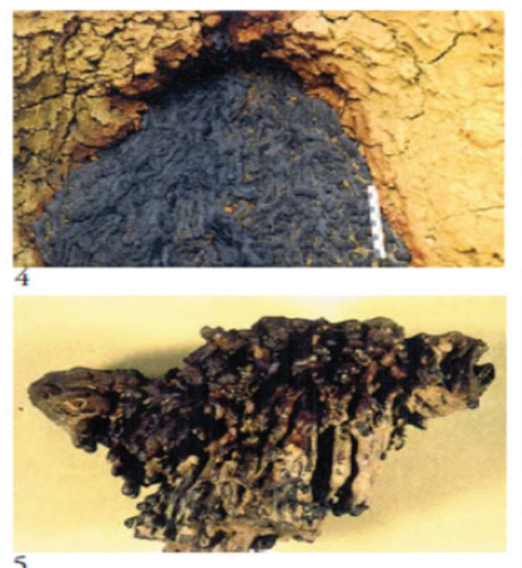

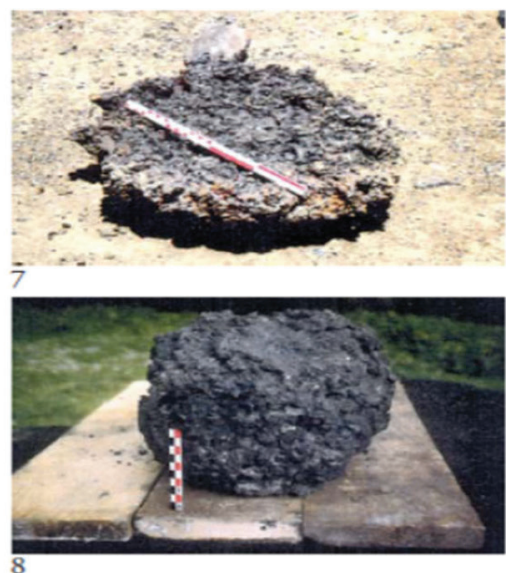

Figura 3. (1) Pequeno forno contemporâneo em Burkina Fasso (2) Reconstituição experimental étnico-arqueológica de um forno pequeno; (4) Escória densa expelida de um forno; (5) Escória - sítio arqueológico de Danawel no Senegal - 1995 (7) Esponja de ferro reduzido com impurezas contemporânea. Missão étnico-arqueológica, sítio de Toungaré (Burkina Faso); (8) Reconstituição étnico-arqueológica. ${ }^{23}$

material de ferro/aço produzido nesse processo, portanto, tem alto grau de impureza e precisa passar ainda por refinamento. ${ }^{23}$

O refinamento consiste em remover o excesso de impurezas, fazendo uso de martelagem com ou sem aquecimento. A moldagem é a etapa final, na qual, o ferro/aço produzido ganha utilidade. Os lingotes de ferro eram moldados principalmente em facas, enxadas e ferramentas para manipular a madeira e voltadas à agricultura. ${ }^{22,23}$

Os conhecimentos acerca da natureza e suas transformações sempre estiveram relacionados à organização social e cultural da humanidade e em África não foi diferente. Ao se espalhar pelo continente as técnicas de forjaria do ferro era associada a organizações políticas e a religiosidade africanas, destarte, não tinha apenas valor econômico e utilitário aos autóctones africanos.

Até o século 16 d.C, o desenvolvimento técnico e tecnológico africano foi superior ao europeu. ${ }^{24}$ Os povos africanos traficados para o Brasil, originários da África Ocidental e Central, para forma de trabalho do escravismo criminoso trouxeram um vasto acervo de conhecimentos tangentes à matéria e às suas transformações. ${ }^{25}$

As imigrações forçadas de africanos para o trabalho compulsório, no escravismo criminoso, foram realizadas durante um período de mais de 300 anos, tendo variado de regiões, segundo as épocas, e também variados os ciclos de produção no Brasil. Estas variações fizeram com que o Brasil tenha recebido uma imensa diversidade de conhecimentos contidos na mão de obra africana de diferentes condições geográficas. Todos os ciclos de produção do Brasil eram de domínio de conhecimento de diversas regiões africanas (p. 17). ${ }^{25}$

A tecnologia africana de metalurgia do ferro chegou ao Brasil importada do Reino do Congo e depois passaram a ser desenvolvidas em território nacional por africanos e afrodescendentes. ${ }^{24,25}$ Campos acresce que o traslado de conhecimentos de fabrico do ferro tem relação com a tecnologia do cadinho, que é um recipiente cilíndrico de argila refratário adequado para sínteses químicas a altas temperaturas. ${ }^{26}$

Por esses e outros exemplos concordamos que:

... se fizermos recuar a história às origens do conhecimento químico, vamos encontrar em tempos imemoriais, nas mais diferentes civilizações, um grande número de tecnologias químicas, como as relacionadas com a alimentação (cocção, conservação com sal, produção de vinagre, vinho e cerveja); com a extração, produção e tratamento de metais; com a produção de esmalte e corantes; com o fabrico de utensílios de cerâmica, vidro, porcelana e metal; com a produção de pomadas, óleos aromáticos e venenos; com técnicas de mumificação; com a produção de materiais de construção como argamassa, tijolos, ladrilhos etc. (p. 21). ${ }^{15}$

Desse modo, compreendemos que somos um país forjado pela contribuição histórica e cultural de diferentes matrizes étnicas e essa visão deve ser consumada no currículo em ação deslocando-o epistemologicamente para abordar, entre outras, as experiências legadas pelas populações negras. Ou seja, professores de química ao concretizarem o currículo na sala de aula devem valorizar e representar adequadamente a pluralidade de matrizes formadoras de nossa sociedade e não somente a matriz europeia.

Reduzir africanos e afrodescendentes a peças produtivas dos modos de produção é desumanizar a história e menosprezar as experiências e o legado deste segmento para humanidade. É preciso desconstruir a ideia de "escravo" historicamente elaborada no Brasil, na qual eles são vistos como selvagens, ignorantes, sem cultura e incapazes de produzir conhecimentos. ${ }^{24,25}$ Nossos ancestrais negros produziram conhecimentos e tecnologias que não deveriam ser suprimidos por ideologias racistas que ainda persistem no imaginário social.

Vamos agora à análise do Extrato 2/C9 denominado "Balança Egípcia: sobre Experimentação e Racismo?":

Extrato 2/C9: Balança Egípcia: sobre Experimentação e Racismo?

267. PF1: O que vocês acham que vai acontecer?

268. Alunos: Vai pegar fogo.

269. PF1: Vai pegar fogo.

270. A7: E depois vai virar só o pó.

271. PF1: O que vocês acham que vai ficar mais pesado depois que pegar fogo?

272. A4: $O$ que pegou fogo.

273. PF2: Por que?

274. A5: Por causa do, do aaah...

275. PF2: Vamos ver, vamos fazer.

277. PF2: Calma gente, vamos lá, vamos fazer.

278. PF1: Vamos por fogo, vocês querem nesse ou nesse? 279. Alunos: Nesse.

289. A4: Tá fedendo o cabelo da A7 queimado professor.

290. A7: Tá fedendo seu cabelo naquele dia que eu fui lá na sua casa.

293. PF2: Põe fogo. 
294. A1: Põe fogo nesse daqui.

297. PF1: Mas aqui já dá para a gente falar de transformação.

298. A?: Não dá não, tá igualzinho.

299. A7: Tá não, ele tá mais escuro.

300. A2: Tá mais escuro.

301. PF1: Tá mais escuro.

304. PF2: Vamos continuar botando fogo.

312. PF2: Vamos equilibrar essa balança.

313. PF1: Oh, vamos ver o que vai acontecer, vou por nesse agora.

317. A13: Assopra.

318. PF1: Não assopra.

319. A7: Acho que o cabelo da AX é melhor.

320. PF1: Vocês estão observando o que está acontecendo aqui, além de ficar escuro.

321. A2: A cor tá diferente.

322. PF2: $O k$.

323. A13: Parece que tá se comprimindo.

324. PF2: Нuиum.

325. A6: $O$ tamanho tá diminuindo.

326. PF2: Legal.

334. A4: Palha de aço, eu acho que se fosse o cabelo da $A X$ já tinha pegado fogo.

335. A6: Se fosse o cabelo da AX ia fazer vrrrrum.

341. A2: isso é preconceito com o cabelo.

No Extrato 2 os alunos A4, A6 e A7 nos turnos 289, 319, 334 e 335 em meio a realização do experimento - em que se utiliza de uma balança de pratos para comparar os pesos antes e depois de uma transformação química, quando utilizamos a esponja de aço e a queimamos para evidenciar o consumo de oxigênio do ar atmosférico e o consequente aumento de massa da esponja que queimava (Equação 3) - fazem referência, de forma pejorativa, ao cabelo crespo de uma colega e os professores não se atentam à situação. Como mostra o Extrato 2 há uma ausência de turnos de fala dos professores em relação a essa situação.

Situações semelhantes a essas são comuns na trajetória escolar de jovens negros e negras na escola onde ocorrem

(...) as primeiras experiências públicas de rejeição do corpo vividas na infância e adolescência. A escola representa uma abertura para a vida social mais ampla, em que o contato é muito diferente daquele estabelecido na família, na vizinhança e no círculo de amigos mais íntimos. Uma coisa é nascer criança negra, ter cabelo crespo e viver dentro da comunidade negra; outra coisa é ser criança negra, ter cabelo crespo e estar entre brancos (p.45). ${ }^{27}$

A pseudociência raciológica e o modo de produção mercantilista/capitalista emergentes nos tempos de colonização europeia no Novo Mundo inferiorizaram e escravizaram o corpo negro, sempre considerando seus sinais diacríticos (cor da pele, cabelo crespo, o nariz), criando-se assim, um padrão de beleza baseado no fenótipo do europeu caucasiano. Esse padrão está presente em nossos dias perseguindo a comunidade negra quando essa ocupa espaços mais amplos da vida social como a escola, por exemplo. ${ }^{27}$

Ainda sobre esse episódio no Extrato 2, o silêncio dos professores pode ter dois motivos. O primeiro é que eles não observaram a situação por estarem atentos ao experimento que não estava dando certo. Os pratos da balança deveriam desequilibrar-se ao passo que a reação acontecesse evidenciando a oxidação do ferro presente na esponja de aço. O prato em que a reação foi executada deveria aumentar a massa e isso não foi observado. Os professores poderiam estar pensando numa estratégia de contornar esse problema.

O segundo motivo é a própria inexperiência de PF1 e PF2 em discutir as relações étnico-raciais na aula de química. Sobre isso concordamos que:

O entendimento conceptual sobre o que é racismo, discriminação racial e preconceito, poderia ajudar os (as) educadores (as) a compreenderem a especificidade do racismo brasileiro e auxiliá-los a identificar o que é uma prática racista e quando esta acontece no interior da escola. Essa é uma discussão que deveria fazer parte do processo de formação dos professores (p. 148). ${ }^{27}$

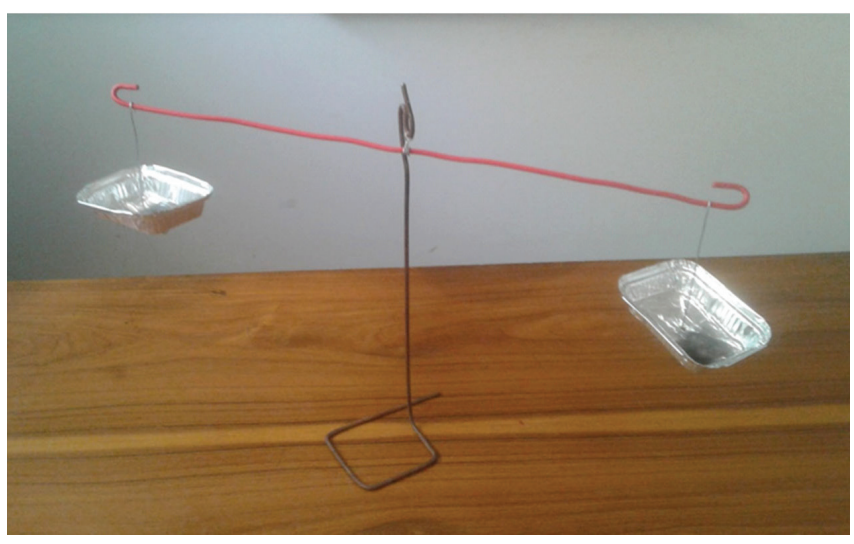

Figura 4. Experimento com a balança. A balança está mais inclinada à direita devido à oxidação da esponja de aço queimada

O racismo contra a população negra é um fenômeno estrutural de opressão e hierarquização fundamentado pela construção social da categoria raça que atinge este segmento em todos os níveis da vida social, a saber, o nível pessoal, o interpessoal e o institucional. Portanto, o racismo anti-negro nem sempre se apresentará de forma explícita, mas também em situações sutis que demandarão formação profissional e pedagógica dos professores e professoras de Química para que se somem aos esforços na luta antirracista. ${ }^{28}$ É preciso que os cursos de formação inicial e de formação continuada contemplem, obrigatoriamente, a educação para as relações étnico raciais. Contudo, acreditamos que esse preparo deve ser concomitante a ações objetivas e reais no ambiente escolar que prestigiem a história e cultura negra construindo uma visão positiva da comunidade negra, porque aprender esses conceitos com a prática é que possibilita uma reconfiguração de valores, primeiramente, em nós professores. ${ }^{27}$

Mais do que o conhecer a lei 10.639/2003 e as diretrizes para ERER, os valores aprendidos devem estar aplicados a nossa atuação como profissionais na sala de aula. É comum que nessas fases iniciais de uma formação haja confusão e mistério, porém, "em questão de poucos anos ou mesmo meses, alguns estudantes começam a produzir em quantidade significativa daquilo que eles e seus instrutores consideram como sendo um design competente... (p. 127)". ${ }^{29}$

O Extrato 2 apresenta ainda a execução de um experimento com uma balança de pratos (Figura 4) que envolve aspectos introdutórios ao ensino do conceito de reação química, "na qual uma ou mais substâncias (os reagentes) são transformadas em uma ou mais substâncias diferentes (os produtos) (p.15, grifos nossos)" ${ }^{30}$ Ou seja, uma reação química é um processo no qual os átomos dos elementos constituintes dos reagentes são rearranjados espacialmente formando desse modo uma nova configuração de átomos formando o que chamamos de produtos.

A reação que foi executada no experimento desenvolvido no 
Extrato 2 é representada pela Equação 3 abaixo na qual o ferro zero presente na esponja de aço consome oxigênio atmosférico produzindo óxido de ferro III:

$$
4 \mathrm{Fe}_{(\mathrm{s})}+3 \mathrm{O}_{2(\mathrm{~g})} \stackrel{\text { calor }}{\longrightarrow} 2 \mathrm{Fe}_{2} \mathrm{O}_{3(\mathrm{~s})}
$$

Os alunos reconheceriam a reação acima pelas evidências que caracterizam uma transformação química. As evidências observadas foram a mudança de cor apontadas no turno 299 por A7, turno 300 por A2 e turno $\mathbf{3 0 1}$ por PF1; a liberação de luz e calor mediante a queima da esponja de aço indicada na observação dos alunos no turno 268. O objetivo do experimento era mostrar que além da mudança de cor a oxidação do ferro provocada pela queima da palha de aço seria notado um aumento de massa como evidência da reação representada pela equação química (Equação 3) e Figura 4.

Dessa forma, $\mathrm{PF} 1$ e PF2 discutiram que a diferença de massa que deveria ser observada entre os dois pratos da balança era provocada pelo acréscimo de oxigênio em parte da esponja que foi oxidada na reação. No entanto, durante a execução deste experimento com a esponja de aço fomos surpreendidos por não haver efeito visível da mudança de massa que deveria provocar um desequilíbrio entre os pratos da balança. A PF2 sugere que continuem colocando fogo (turno 304) e PF1 sugere que equilibrem a balança.

Visto que o que se queria observar não foi possível, naquele momento, nossa estratégia foi a de trocar as porções de esponjas por duas bolas de papel que eram mais uniformes e, em apenas uma delas, colocou-se fogo havendo outra transformação como segue a discussão no Extrato 3/C9 chamado "Conservação de Massas e o Conceito de Reação Química”:

\section{Extrato 3/C9: Conservação de Massas e o Conceito de Reação Química \\ 364. PF1: ... E com o papel o que vocês acham que vai acontecer? \\ 365. A?: Eu acho que vai ficar pesado. \\ 366. A7: Eu acho que vai ficar leve. \\ 367. A4: Não acredito! (Alunos observando o fenômeno da queima do papel na balança).}

368. A?: Que legal

369. A6: Uai professor, o papel virou essa fumaça.

370. PF2: Tá, vocês que estão aí do lado não devem ter visto muito bem, mas quando esse daqui queimou, o que a balança que estava equilibrada fez? Ela fez isso aqui, bem pouquinho, mas fez isso aqui, quê que significa? (Mostrando o desequilíbrio entre os pratos).

372. PF2: O que isso significa? Qual lado é mais pesado? Esse daqui ele está mais para baixo né, não deixe os queimados ... certo. O que aconteceu? Isso aqui era meu estado inicial e esse aqui é meu estado final.

373. Alunos: Final. 90

374. PF2: Final, muito bem, alguma coisa daqui para cá mudou?

375. Alunos: Sim

376. PF 2: Tem a transformação, aqui ocorreu uma transformação aí, o quê que mais que mudou? Isso aqui continua sendo o papel?

377. Alunos: Não.

378. PF2: Não! Mudou a identidade do papel, o que eu tenho aqui, cinzas, exatamente, não é bem a identidade do material que eu tenho aqui, daqui para cá, além de ocorrer uma transformação ocorreu também uma?! Alguém falou, eu escutei, ocorreu uma?!

379. A4: Uma diferença de massa.
380. A6: Reação.

381. PF2: Reação.

385. PF2: .... Vocês entenderam o que aconteceu aqui? Vocês entenderam?

386. A6: Entendi

388. A6: Sim, professora.

389. PF2: ... olha só, o quê que aconteceu do estado inicial para o estado final?

390. A6: Transformação.

391. PF2: Transformação, isso, mudou a identidade do meu material e então também aconteceu uma transformação química, muito bem, mas porque que a massa mudou? Porque eu pus essa balancinha aqui justamente para a gente comparar as massas, as massas estavam iguais, a massa desse lado com esse lado estava igual, não estava? Depois que botou fogo no papel o que aconteceu com essas massas?

392. A7: $O$ que tinha colocado fogo.

393. PF2: O que tinha pegado fogo. Mas espere aí, por que se é tudo papel? O quê que aconteceu?

394. A1: Porque ocorreu oxidação.

395. PF2: Hã? Pode falar.

396. A7: Por causa da reação química.

399. A13: Carbono mais oxigênio.

400. PF2: Isso, no papel a gente tem o quê? Carbono, aqui eu só representei o carbono, no papel a gente tem carbono, quando esse papel pega fogo ele reage com o?!

401. Alunos: Oxigênio.

408. PF2: Isso, então a gente tem fogo enquanto tem oxigênio, porque? Porque está acontecendo uma reação com esse oxigênio, acabou papel, acabou o fogo. Tá bom, mas porque a massa de um ficou menor do que a massa do outro? Se no início eram todos com a massa igual?

409. A7: Porque um vai oxidar.

410. PF2: O que aconteceu aqui, o carbono quando reage com o oxigênio ele forma quem?

411. Alunos: $\mathrm{CO} 2$

412. PF2: O gás carbônico, como o nome CO2, que é um gás, não é?! E o que acontece com o gás quando ele é formado? 413. A? Evapora.

414. PF2: Não, ele é liberado.

415. A6: Aquela fumaça era o...

416. PF1: O CO2. 91

417. PF2: O CO2 sendo liberado, sendo formado?

418. Alunos: $O$ gás.

419. PF2: $O$ gás, muito bom. Isso daqui é a representação da reação química (ei). Isso daqui é representação da reação química que aconteceu, porque que a massa de um, é, diminuiu? Porque ela sofreu combustão, essa reação com o oxigênio aqui a gente chama de combustão.

Ao substituirmos a esponja de aço pelo papel, ação materializada no Extrato 3 de $\mathrm{C} 9$ acima, para contornarmos o inesperado problema que tivemos com a balança no uso da esponja de aço observamos a reflexão-na-ação de PF1 e PF2. Reflexão-na-ação que é:

...um presente-da-ação, um período de tempo variável como contexto, durante o qual ainda se pode interferir na situação em desenvolvimento, nosso pensar serve para dar nova forma ao que estamos fazendo, enquanto ainda ofazemos. Eu diria, em casos como este, que refletimos-na-ação (p. 32). ${ }^{29}$

Assim, no diálogo acima - turnos 364 a 419 - PF2 discute uma das leis importante para a compreensão do conceito de reação química: a 
Lei de Conservação de Massas: as transformações químicas refletem um rearranjo de átomos, logo, em um sistema fechado a massa antes e depois da reação química permanece constante. ${ }^{31}$

PF2 discutiu sobre a reação química de combustão da celulose a partir do fenômeno observado no experimento com a balança de pratos. Nos turnos 370 e 372 PF2 descreve o experimento: o lado em que o papel foi queimado perdeu massa como apontado na contrapalvra de A6 no turno 369: "o papel virou fumaça". Segundo o discurso de PF2 no turno 372, o desequilíbrio observado entre os pratos da balança reflete o estado inicial e o estado final da reação química.

A reação descrita por estes turnos foi a reação de combustão. A combustão é uma transformação química na qual um combustível é oxidado por um comburente. Dessa forma, podemos considerar combustíveis os materiais ou substâncias cuja energia liberada na oxidação possa ser aproveitada. ${ }^{32}$ A oxidação do carbono da celulose acontece por intermédio da combinação do mesmo com o oxigênio presente na atmosfera. No turno 400, PF2 questiona aos alunos com qual substância o carbono da celulose reagiu e, no turno 401, os alunos identificam a participação do $\mathrm{O}_{2}$, quando em coro exclamam: "Oxigênio! ".

No turno 408 e 410, PF2 questiona a causa do desequilíbrio entre os pratos da balança. A combustão incompleta da celulose produziu o carbono grafite (cinzas), dióxido de carbono e água gasosa (fumaça). $\mathrm{O}$ desprendimento dos gases produzidos e da água gasosa levam ao desequilíbrio dos pratos. Os alunos dão um retorno positivo às questões levantadas por PF2 quando nos turnos 409 e 411 se referem a causa do desequilíbrio como a oxidação e formação de $\mathrm{CO}_{2}$.

O conceito de reação química é de difícil aprendizagem, pois discorre sobre fenômenos muito distintos, por exemplo: a combustão da celulose, a oxidação da esponja de aço, a saponificação, a neutralização de um ácido por uma base, a fotossíntese etc. ${ }^{31}$ Além disso, alguns alunos enfrentam obstáculos ao entendimento da diferença entre transformação química e mudança de estado físico, fato confirmado no turno 413 quando $A$ ? (Aluno não identificado) se refere a formação de dióxido de carbono como evaporação (mudança de estado).

Porém, PF2 corrige A? no turno subsequente (turno 414) aplicando a linguagem química de forma correta: "Não, ele é liberado.". Rosa e Schnetzler enumeram também dificuldades correlatas à aprendizagem do conceito de reação química elencando possíveis concepções alternativas. ${ }^{32}$ Por exemplo, alguns alunos empregam no nível microscópico o que observam no nível macroscópico do fenômeno impedindo que construam explicações para os fenômenos coerentes às formas científicas. Essas dificuldades relacionadas a compreensão de que as mudanças químicas são consequências de rearranjos atômicos influenciam na correta apropriação da Lei de Conservação de Massas. ${ }^{33}$

Convém registrar também que no turno $400 \mathrm{PF} 2$ refere-se à reação química realizada no experimento como sendo a reação do carbono (C) da celulose $\left(\mathrm{C}_{6} \mathrm{H}_{10} \mathrm{O}_{5}\right)$ com o oxigênio $\left(\mathrm{O}_{2}\right)$ simplificando, em termos de linguagem e representação químicas corretas, a transformação química que realmente ocorreu. As evidências observadas na realização do experimento - formação de cinzas preta e liberação de gás (fumaça) - deveriam propiciar a discussão da combustão incompleta da celulose conforme Equações 4, 5 e 6 a seguir:

$$
\begin{aligned}
& \mathrm{C}_{6} \mathrm{H}_{10} \mathrm{O}_{5(\mathrm{~s})} \stackrel{\text { calor }}{\longrightarrow} 6 \mathrm{C}_{(\mathrm{s}, \text { grafite) }}+5 \mathrm{H}_{2} \mathrm{O}_{(\mathrm{g})} \\
& \mathrm{C}_{6} \mathrm{H}_{10} \mathrm{O}_{5(\mathrm{~s})}+6 \mathrm{O}_{2(\mathrm{~g})} \stackrel{\text { calor }}{\longrightarrow} 6 \mathrm{CO}_{2(\mathrm{~g})}+5 \mathrm{H}_{2} \mathrm{O}_{(\mathrm{g})}
\end{aligned}
$$

Tendo por base o referencial histórico-social de ensino aprendizagem, podemos inferir que, nesse momento mediado pelo professor, o uso adequado da linguagem química propicia ao discente internalizar essa nova cultura, a qual está sendo apresentado, que é o conhecimento científico escolar químico de forma mais satisfatória. Pensamento e linguagem à medida que a ser humano se desenvolve tornam-se cada vez mais inter-relacionados de modo que a linguagem é meio pela qual o pensamento se processa e é também por ela externado. ${ }^{34}$ Por conseguinte, o professor deveria utilizar a linguagem química da forma adequada, pois, se assim não fizer, o sujeito que é aprendiz na cultura química, sendo educado com o emprego inadequado da linguagem, poderá ter dificuldades para aprender os conteúdos sucessores do currículo da Química.

\section{CONCLUSÕES}

A partir desse ciclo chegamos ao entendimento de que planejar e executar uma aula de Química pensando no deslocamento epistêmico demandou conhecimentos que foram suprimidos de nossa grade curricular na formação inicial o que demandou pesquisa e formação em serviço tanto de alunos e orientadora. O professor de Química lida com uma escola real que é reflexo da sociedade em que está inserida, logo, a formação desse profissional deveria prepará-lo para também compreender o fenômeno do racismo na escola e saber como agir quando ele se apresentar em seu ambiente de trabalho.

Lutas históricas do povo negro culminaram em leis e diretrizes atuais que legitimam o ensino de cultura e história africana e afro-brasileira, assim como, a educação para as relações étnico-raciais. No entanto, a concretização desses aparatos legais no currículo em ação no ensino superior, nas licenciaturas em química, está aquém do esperado. É preciso que, sendo as universidades públicas formadoras dos profissionais que implementam a lei 10.639/2003 e suas diretrizes na sala de aula da educação básica, a grade curricular, as ementas das disciplinas dos cursos universitários devem incluir a temática proposta. Assim professores e professoras em formação inicial estarão munidos dos pressupostos teórico-metodológicos que poderão orientar a ação docente em aula.

Nossos resultados mostraram ser possível discutir em uma aula de Química temas referentes às propostas das referidas leis, assim como abordar conceitos de química correlatos. Para isso, foram mobilizados conhecimentos que não estavam presentes na grade curricular da licenciatura em Química e, por isso, demandou formação em serviço por intermédio do grupo de estudos instituído pelo Coletivo Ciata.

O Coletivo Ciata estruturou uma disciplina no curso de licenciatura que procura superar essa lacuna no curso de licenciatura em Química da UFG, porém, a disciplina ainda é do núcleo optativo. Todavia, consideramos imperativo que os cursos de licenciatura em Química reservem momentos obrigatórios nas grades curriculares, principalmente em disciplinas que lidam diretamente com o ensino de Química, para discussão das relações étnico-raciais e as possibilidades de implementação da lei 10.639/2003 na especialidade. A escola, enquanto microcosmo social, reproduz em menor escala as ideologias e tensões presentes na sociedade como um todo. Portanto, o professor deve ser formado com vistas a ter o conhecimento necessário para trabalhar nesta escola real e não na escola ideal que só mantém as coisas como estão e não transforma a realidade. ${ }^{35}$

\section{AGRADECIMENTOS}

Agradecemos ao Colégio Estadual Andrelino Rodrigues de Morais pela profícua parceria.

\section{REFERÊNCIAS}

1. Alterada pela Lei $11.645 / 2008$ que também altera a LDB de 1996 tornando obrigatório o ensino de cultura e história africana e afrobrasileira e cultura e história indígena. 
2. Santana, J. V. J.; Alves, J. S.; Revista África e Africanidades 2010, 8, 1.

3. Passos, J. C.; Rodrigues, T. C.; Cruz, A. C. J.; Revista da ABPN 2016, $19,8$.

4. Carmo, N. L.; Bufrem, L. S.; Correia, A. E. G. C.; Anais do XVI Encontro Nacional de Pesquisa em Ciência da Informação, João Pessoa, Brasil, 2015.

5. Silva, G.; Araújo, M. Em História da Educação do Negro e outras histórias; Romão, J., ed.; Secretaria de Educação Continuada, Alfabetização e Diversidade: Brasília, 2005, cap. 4.

6. Richter, L.; Lopes, G. M. N.; Freitas, D.; Anais do II Seminário Nacional De Filosofia e Educação, Santa Maria, Brasil, 2006.

7. Gomes, N. L.; Currículo sem Fronteiras 2012, 12, 98.

8. Gonçalves, L. R. D.; Revista Educação e Políticas em Debate 2013, 2, 1.

9. Benite, A. M. C.; Bastos, M. A.; Camargo, M. J. R.; Lima, G. L. M.; Vargas, R. N.; Quim. Nova Esc. 2017, 39, 131.

10. Brandão, Z.; Cadernos de Pesquisa 2010, 40, 849.

11. Beltran, M. H. R.; Saito, F.; Trindade, L. S. P.; História da Ciência na Formação de Professores, $1^{\text {st }}$ ed., Editora Livraria da Física: São Paulo, 2014.

12. Universidade Federal de Goiás, U. F. G., Instituto de Química, 2017.

13. Marcuschi, L. A.; Análise da Conversação, $18^{\text {th }}$ ed., Ática: São Paulo, 1986.

14. Castilho, A.; A Língua falada no ensino de português, $1^{\text {st }}$ ed., Contexto: São Paulo, 2002.

15. Chassot, A. I.; Quim. Nova Esc. 1995, 1, 20.

16. Silva, R. A.; Isto não é Magia; é Tecnologia: subsídios para o estudo da cultura material e das transferências tecnológicas africanas 'num' novo mundo, $1^{\text {st }}$ ed., Ferreavox: São Paulo, 2013.

17. Paiva, E. F. Em $O$ trabalho mestiço; maneiras de pensar e formas de viver: séculos XVI a XIX; Paiva, E. F., Anastasia, C. M. J., orgs.; Annablume / PPGH UFMG: São Paulo/Belo Horizonte, 2002, cap. 10.

18. Alvino, A. C. B.; Moreira, M. B.; Lima, G. L. M., Silva, J. P.; Moura, A. R.; Silva, A. G.; Faustino, G. A. A.; Bastos, M. A.; Benite, A. M. C.; Anais do XVIII Encontro Nacional de Ensino de Química, Florianópólis, Brasil, 2016.
19. Machado, C.E.D.; Ciência, tecnologia e inovação africana e afrodescendente, $1^{\text {st }}$ ed., Editora Bookess: São Paulo, 2014.

20. Santos Júnior, R. N.; Revista África e Africanidade 2010, 3, 11.

21. Medeiros, M. A.; Quim. Nova Esc. 2010, 32, 208.

22. http://ftp.demec.ufpr.br/disciplinas/TM343/A\%C7OS.pdf, acessada em junho de 2019.

23. Fluzin, P. Em The Origins of Iron Metallurgy in Africa New light on its antiquity: West and Central Africa, $1^{\text {st }}$ ed.; Bocoum, H., ed.; UNESCO: Paris, 2004, cap. 4.

24. Cunha Júnior, H. A.; Revista Espaço Acadêmico 2015, 166, 104.

25. Cunha Júnior, H.; Tecnologia Africana na Formação Brasileira, $1^{a}$ ed., CEAP: Rio de Janeiro, 2010.

26. http://www.arqueologia-iab.com.br/publications /download/14, acessada em junho de 2019.

27. Gomes, N. L.; Revista Brasileira de Educação 2002, 21, 40.

28. Werneck, J.; Racismo Institucional: uma abordagem conceitual, $1^{\text {st }}$ ed., Trama Design: Rio de Janeiro, 2013.

29. Schön, D.; Educando o Profissional Reflexivo: um novo design para o ensino e a aprendizagem, $1^{\text {st }}$ ed. Artmed: Porto Alegre, 2000.

30. Kotz, J. C.; Treichel, P. M.; Townsend, J. R.; Treichel, D. A.; Química Geral e Reações Químicas v.1, $9^{\text {th }}$ ed., Cengage Learning: São Paulo, 2015.

31. Mortimer, E. F.; Miranda, L. C.; Quim. Nova Esc. 1995, 1, 23.

32. http://www.fem.unicamp.br/ em672/GERVAP1.pdf, acessada em junho de 2019.

33. Rosa, M. I. F. P. S.; Schentzler, R. P.; Quim. Nova Esc. 1998, 4, 31.

34. Vygotsky, L. S.; A formação social da mente: o desenvolvimento dos processos psicológicos superiores, $7^{\text {th }}$ ed., Martins Fontes: São Paulo, 2007.

35. Este trabalho é uma versão revisada de parte da dissertação de mestrado de Marysson Jonas Rodrigues Camargo orientada pela professora Dra. Anna Canavarro Benite pelo Programa de Pós-Graduação em Química do Instituto de Química na Universidade Federal de Goiás, Campus Samambaia, 2018. 